https://doi.org/10.32689/2617-22242021-1(26)-203-225

Польсъка Людмила Олександрівна, аспірант кафедри менеджменту, публічного управління та адміністрування Дніпровського державного аграрно-економічного університету, 49000, м. Дніпро, вул. Сергія Єфремова, 25, тел.: +38 (067) 19803 81, e-mail: mila8118@meta.ua, http://orcid.org/0000-0001-9868-2326

Польская Людмила Александровна, аспирант кафедры менеджмента, публичного управления и администрирования Днепровского государственного аграрно-экономического университета, 49000, г. Днепр, ул. Сергея Ефремова, 25, тел.: +38 (067) 19803 81, e-mail: mila8118@meta.ua, http://orcid. org/0000-0001-9868-2326

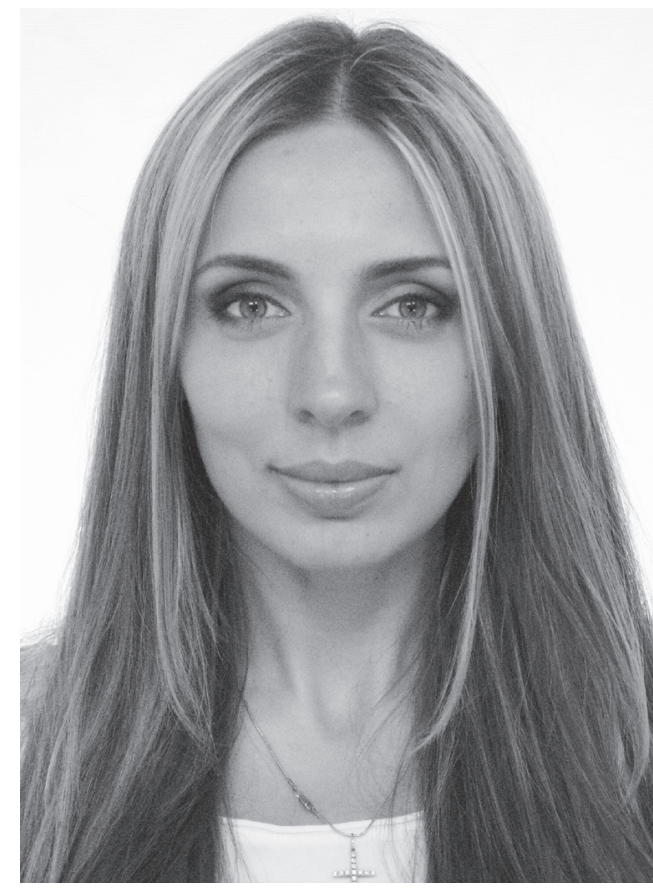

Polska Liudmyla Alexandrovna,

postgraduate student of the Department of Management, Public Administration and Administration of the Dnieper State Agrarian and Economic University, 49000, Dnipro, Str. Serhiy Yefremov, 25, tel.: +38 (067) 19803 81, e-mail:mila8118@meta.ua, http://orcid. org/0000-0001-9868-2326

\title{
АРХЕТИПИ РОЗВИТКУ ФОРМ ПУБЛІЧНО-ПРИВАТНОГО ПАРТНЕРСТВА ДЛЯ ЗАБЕЗПЕЧЕННЯ СТАЛОГО РОЗВИТКУ СІЛЬСЬКИХ ТЕРИТОРІАЛЬНИХ ГРОМАД
}

Анотація. Досліджено основні аспекти взаємодії публічного та приватного сектора. Проаналізовано: розвиток форм публічно-приватної взаємодії за допомогою архетипного підходу; поняття архетипу сільських територій, а також явище публічно-приватного партнерства; основні моделі публічно-приватного партнерства. Запропоновано організаційно-нормативні механізми удосконалення системи публічного управління на засадах публічно-приватного партнерства в контексті забезпечення сталого розвитку сільських територіальних громад. На основі проведеного грунтовного аналізу різних систем та моделей публічно-приватного партнерства було визначено основні сфери сільськогосподарського розвитку та розвитку сільських територіальних гро- 
мад, щодо яких можна ефективно застосовувати інструменти публічно-приватного партнерства 3 метою досягнення сталого соціально-економічного розвитку сільських територій та максимально ефективного використання їх виробничого потенціалу. Також запропоновані шляхи удосконалення нормативно-правової бази, що регулює суспільні відносини у сфері публічно-приватного партнерства. Наголошується на необхідності включення сільськогосподарської сфери до переліку об'єктів публічно-приватного партнерства, визначених у Законі України “Про державно-приватне партнерство”. Доцільно також розширити саме поняття державно-приватне партнерство, використовуючи міжнародний термін “публічно-приватне партнерство”, яке більш точно визначає сутність договірних відносин, між державними та місцевими органами влади з приватними партнерами. В контексті проаналізованих нормативно-правових актів щодо розвитку інституту публічно-приватного партнерства було визначено основні сфери публічно-приватного партнерства задля розвитку сільського господарства та сільських регіонів. Загалом, запропоновано сфери які було б доцільно розвивати в рамках публічно-приватного партнерства, а саме: сфера екологічного землекористування та меліорації, агрострахування, сталий розвиток сільських регіонів за рахунок будівництва інфраструктурних об'єктів та надання послуг громаді. Таким чином, у дослідженні визначено моделі публічно-приватного партнерства, а також сфери їх застосування, що можуть бути використані органами державної влади та місцевого самоврядування для розроблення майбутніх партнерських угод щодо розвитку аграрної сфери та сталого соціально-економічного розвитку сільських територіальних громад.

Ключові слова: державно-приватне партнерство, архетипний підхід, архетип сільської території, моделі публічно-приватного партнерства, аграрна політика.

\section{АРХЕТИПЫ РАЗВИТИЯ ФОРМ ПУБЛИЧНО-ЧАСТНОГО ПАРТНЕРСТВА ДЛЯ ОБЕСПЕЧЕНИЯ УСТОЙЧИВОГО РАЗВИТИЯ СЕЛЬСКИХ ТЕРРИТОРИАЛЬНЫХ ОБЩИН}

Аннотация. Исследованы основные аспекты взаимодействия публичного и частного сектора. Проанализированы: развитие форм публично-частного взаимодействия, с помощью архетипного подхода; понятие архетип сельских территорий и явление государственно-частного партнерства; основные модели государственно-частного партнерства. Предложены организационно-нормативные механизмы совершенствования системы публичного управления на основе государственно-частного партнерства в контексте обеспечения устойчивого развития сельских территориальных общин. На основе проведенного анализа различных систем и моделей государственночастного партнерства, были определены основные сферы сельскохозяйственного развития и развития сельских территориальных общин, для которых можно эффективно применять инструменты государственно-частного партнерства с целью достижения устойчивого социально-экономического 
развития сельских территорий и достижения максимально эффективного производственного потенциала. Также предложены пути совершенствования нормативно-правовой базы, регулирующей общественные отношения в сфере публично-частного партнерства. Подчеркивается необходимость включения сельскохозяйственной сферы в перечень объектов государственно-частного партнерства, согласно Закона Украины “О государственно-частном партнерстве”. Целесообразно также расширить само понятие государственно-частного партнерства, используя международный термин “публично-частное партнерство", которое более точно определяет сущность договорных отношений между государственными и местными органами власти с частными партнерами. В контексте проанализированных нормативно-правовых актов по развитию института государственно-частного партнерства, были определены основные сферы публично-частного партнерства для развития сельского хозяйства и сельских регионов. В общем, предложены сферы, которые было бы целесообразно развивать в рамках государственно-частного партнерства, а именно: сфера экологического землепользования и мелиорации, агрострахование, устойчивое развитие сельских регионов за счет строительства инфраструктурных объектов и предоставления услуг общине. Таким образом, в исследовании определены модели государственно-частного партнерства, а также сферы их применения, которые могут быть использованы органами государственной власти и местного самоуправления для разработки будущих партнерских соглашений по развитию аграрной сферы и устойчивого социально-экономического развития сельских территориальных общин.

Ключевые слова: государственно-частное партнерство, архетипический подход, архетип сельской местности, модели государственно-частного партнерства, аграрная политика..

\section{ARCHETYPES OF DEVELOPMENT OF PUBLIC-PRIVATE PARTNERSHIP FORMS FOR PROVIDING SUSTAINABLE DEVELOPMENT OF RURAL TERRITORIAL COMMUNITIES}

Abstract. The article examines the main aspects of interaction between the public and private sectors. The analysis of the development of forms of publicprivate interaction is carried out, using an archetypal approach are analyzed the concept of the archetype of rural areas and the phenomenon of public-private partnership. The main models of public-private partnership are also analyzed; organizational and regulatory mechanisms for improving the public administration system on the basis of public-private partnership in the context of ensuring sustainable development of rural territorial communities are suggested. Based on the analysis of various systems and models of public-private partnership, the main areas of agricultural development and sustainable development of rural territorial communities were identified, for which the tools of public-private partnership can be effectively applied in order to achieve sustainable socio-economic development of rural areas and their production potential. 
In the article, are proposed the ways for improving the regulatory framework governing public relations in the field of public-private partnership, in general, it concerns the need to include the agricultural sector in the list of objects of public-private partnership defined in the Law "On Public-Private Partnership". It is also advisable to expand the concept of public-private partnership, using the international term "public-private partnership", which more accurately defines the essence of contractual relations between state and local authorities with private partners. In the context of the analyzed regulatory legal acts on the development of the institution of public-private partnership, the main areas of public-private partnership for the development of agriculture and rural regions were identified. In general, are proposed areas that would be advisable to develop within the framework of public-private partnership, namely: the sphere of ecological land use and land reclamation, agricultural insurance, sustainable development of rural regions through the construction of infrastructure facilities and the provision of services to the community.

Thus, the study identifies models of public-private partnerships, as well as their areas of application, which can be used by public authorities and local governments to develop future partnership agreements for the development of the agricultural sector and sustainable socio-economic development of rural territorial communities.

Keywords: public-private partnership, archetypal approach, archetype of rural territory, models of public-private partnership, agricultural policy.

Постановка проблеми. Забезпечення сталого розвитку сільських територій та розвиток їх економічного потенціалу є основною задачею в контексті затвердженої Концепції розвитку сільських територій від 23 вересня 2015 № 995-р. [1], одним із шляхів її досягнення $є$ розвиток співпраці між органами державної влади, органами місцевого самоврядування та приватного сектору на засадах публічно-приватного партнерства. Зважаючи на недостатність фінансування, як з боку державного, так і місцевих бюджетів на вирішення всіх нагальних питань в сільській місцевості, дана форма співпраці в поєднанні з ресурсними можливостями держави і місцевих громад та фінансових інвестицій, нових технологій та інновацій з боку приватних партнерів сприятимуть більш ефективному впровадженні проектів соціально-економічного розвитку сільських територій. Тому, для розвитку публічно-приватного партнерства в сільських регіонах, необхідно дослідити міжнародний досвід застосування даного інструменту співробітництва, а також різні моделі публічно-приватного партнерства, і визначити сфери та об'єкти публічно-приватного партнерства для сільського господарства. Даний симбіоз ресурсів та можливостей сприятиме загальному процвітанню сільських громад, активній участі громадян у розбудові своїх територій, розвит- 
ку необхідних для громади сфер господарської діяльності, соціального забезпечення послугами, розбудові інфраструктурних об'єктів, стимулюванню впровадження екологічних технологій в землеробстві та інших важливих сферах сільського життя. В статті проаналізовано архетип сільської території, проаналізовано історичний досвід запровадження інструменту публічно-приватного партнерства, запропоновані нормативно-правові та адміністративно-інституційні механізми удосконалення форми публічно-приватного партнерства щодо управління об'єктами публічно-приватного партнерства. Запропоновано використання моделі "публічно-приватного" партнерства для запровадження сталих методів землекористування та охорони грунтів, розвитку сфери інфраструктури та надання послуг в сільській місцевості, а також розвиток аграрного страхування на засадах публічно-приватного партнерства. Загалом, в статті наголошується на важливості розширення переліку об'єктів, в рамках публічно-приватного партнерства, а також збереженні права власності та контролю за даними об'єктами і відповідальності за їх ефективне використання для досягнення цілей сталого розвитку сільської територіальної громади.

Аналіз останніх досліджень і публікацій. Дослідженням проблематики “архетипу територій” та його впливу на державну політику вивчали в своїх працях: В. Ю. Глеба [2], О. Ковінчук [3]. Архетипний підхід в публічному управлінні та сучасні дослідження соціальної дійсності вивчали: Е. Афонін, Т. Плахтій [4],
А. Макарова [5; 6]. Актуальні питання теорії та практики публічно-приватного партнерства в Україні досліджені в працях таких науковців як: І. К. Бистряков, Д. В. Клиновий [7], А. В. Степаненко, А. А. Омельченко [8], Н. А. Третяк, О. В. Каленська [9]. Проблематикою історії явища публічно-приватного партнерства та його розвитку в сучасних умовах, займались зарубіжні вчені та дослідники: M. Rankin, T. G. Nogales [10], F. Herman, F. Geerling-Eiff, J. Potters, L. Klerkx [11], M. J. Romero [12], N. D. Caldwell, J. K. Roehrich, G. George [13]. Механізми публічно-приватного партнерства, як інструмент для досягнення сталого розвитку сільських територій, досліджували такы науковці, як: А. М. Статівка, I. Н. Кульчій [14; 15], В. М. Онегіна, Л. А. Батюк [16], Т. П. Кальна-Дубнюк, М. В. Бесчастна [17]. Питання розвитку публічно-приватного партнерства в аграрному секторі досліджувались такими вченими, як: О. В. Жавнерчик [18], П. Ф. Кулинич [19], М. Ф. Кропивко, М. М. Ксенофонтов, Н. В. Хміль [20], М. Козін, Г. Пирченкова, О. Радченко [21], П. Шилепнитський [22], Л. О. Шашула, І. С. Денисенко [23]. Розвиток аграрного страхування на засадах публічно-приватного партнерства вивчали: Н. С. Танклевська, В. В. Яромоленко[24], К. В. Третяк [25], Н. О. Шипшанова, С. С. Совщак, Ю. В. Мельник [26], А. М. Стельмащук [27] та інші. Проте недостатньо досліженою є тема розвитку моделей публічно-приватного партнерства та можливості їх використання та адаптації до умов застосування в аграрному секторі України. 
Мета статті - архетипний аналіз поняття сільської території, явища публічно-приватного партнерства, розробка концептуальних засад використання механізму державно-приватного партнерства в сфері аграрного виробництва та сталого розвитку сільських територій.

Виклад основного матеріалу. Сталий розвиток став новою ідеологією розвитку суспільства XXI ст., а також є альтернативою парадигмі економічного зростання, за екстенсивною моделлю господарської діяльності, яке ігнорувало екологічну складову життєдіяльності суспільства. За визначенням Комісії ООН зі сталого розвитку, головна мета сталого розвитку суспільства - задоволення потреб теперішнього покоління, не ставлячи під загрозу здатність майбутніх поколінь задовольняти свої потреби [28]. Отже, сталий розвиток громади - це керований комплексний соціально-економічний та екологічний розвиток території направлений на задоволення потреб громади із врахуванням потреб майбутніх поколінь. Для забезпечення сталого соціально-економічного розвитку території потрібно максимально ефективно використовувати наявний потенціал громади, враховуючи історично обумовлені критерії виникнення та розвитку території, географічне розташування, наявні природні ресурси та культурні особливості громади, що в свою чергу і складає архетип території. Поняття “архетип території” в своїх наукових працях визначив В. Ю. Глеба - як історичне ядро міста, що має чітко виражені функціонально-стилістичні особливості [2]. Дана дефініція ви- значає архетип території лише міста, і не враховує архетип сільської території. Але, саме сільська територія є архетипом, “праобразом" сьогоднішніх міст і сіл, тому визначення архетипу території потрібно розглядати в контексті зародження та розвитку саме сільських територій. Сільські території являються колискою національної ідентичності народу, його духовності, що в свою чергу впливає на несвідоме емоційне самовираження народу, поведінку громадян та визначає майбутній розвиток держави. Архетип сільської території визначається як історичний, територіально-функціональний та культурологічний праобраз розвитку сучасної територіальної громади. Вивчення проблематики архетипу території являється дуже важливим для розвитку науки публічного управління, адже дослідження праобразів суспільства дає можливість спрогнозувати його поведінку та майбутній розвиток, що $є$ надважливим для розробки державної політики та механізмів публічного управління і їх ефективного впровадження. Таким чином, удосконалення механізмів публічного управління аграрним сектором економіки та сталого розвитку сільських територіальних громад є запорукою успішного проведення земельної реформи, покращення якості життя та добробуту в сільських територіальних громадах.

Одним із таких механізмів є публічно-приватне партнерство. Даний механізм не являється новою формою співпраці для публічного та приватного сектора. Насправді концесії, як найпоширеніша форма ППП, за якими приватний інвестор працює, 
підтримує та здійснює розвиток інфраструктури або надає послуги із загальним економічним інтересом - датуються тисячами років. Ще за часів Римської імперії, концесії служили інструментами для будівництва доріг, громадських лазень та організації роботи ринків. Інші відомі приклади включають середньовічну Європу, де вже в 1438 р. французький дворянин на ім'я Луїс де Бернам отримав в концесію річку Рейн, щоб стягувати плату за організацію перевезення по ній. Прикладів існує багато, так з початку XVII-XVIII століття, багато об'єктів інфраструктури (водні канали, дороги, залізниці) у Європі, а потім і в Америці, Китаї та Японії фінансувались приватним шляхом за концесійними договорами. Хоча ця практика існує тисячоліття, термін "публічно-приватне партнерство" (далі - ППП) був винайдений і популяризований в 1970-х роках, коли неоліберальні ідеї почали ставити під сумнів домінуючу раніше кейнсіанську парадигму про необхідність активної ролі держави в економіці в контексті низьких економічних показників, за що звинувачували уряд в його неефективності. Згодом, в 80-х роках з'явились нові ідеї щодо нової моделі державного управління New Public Management (NPM) - це підхід, який використовує нові підходи управління в державному секторі для підвищення ефективності організації державної служби та діяльності державних установ та організацій, запроваджуючи механізми управління, які використовуються в приватному секторі. У цьому контексті ППП часто використовувались як альтернатива бюрократичним державним службам та неефективним державним підприємствам. Було аргументовано, що передача державних повноважень та завдань для їх виконання приватним суб'єктам є основним засобом зменшення ролі держави, підвищення ефективності надання державних послуг, а також зменшити процес витіснення приватного сектора державними підприємствами [29]. В основному, ППП використовуються для інфраструктурних проектів, таких як будівництво та облаштування дитячих садків, лікарень, транспортних систем, систем водопостачання, зрошення та інших інфраструктурних об'єктів.

В міжнародній практиці термін державно-приватне партнерство "public-private partnership" ("PPP") використовується як форма співпраці між державними органами та бізнесом, метою якого є фінансування, будівництво, оновлення, управління, обслуговування інфраструктури або надання послуг (Європейська комісія) [30]. Публічно-приватне партнерство спрямоване на фінансування, розробку, впровадження та функціонування об'єктів та послуг державного сектору і характеризується наданням довгострокових (іноді до 30 років) послуг; розподілом частини ризику з приватним сектором і включають різні форми довгострокових контрактів, укладених між юридичними особами та органами влади (Свропейська економічна комісія ООН) [31]. В своєму дослідженні ми будемо використовувати термін "публічно-приватне партнерство” (далі - ППП), що є еквівалентом категорії “державно-приватне партнерство”, на нашу думку, остан- 
нє не зовсім відповідає нормам ЗУ "Про державно-приватне партнерство”, так як до державних партнерів законодавством визначені не лише органи державної влади, а й органи місцевого самоврядування. А отже, поняття "публічно-приватне партнерство” більше відповідає сутності терміна публічно-приватного співробітництва, щодо об'єктів державної та комунальної власності, і загальноприйнятому міжнародному визначенню "public-private partnership" (PPP, 3P, or P3).

3 часом, в світі сформувалися різні моделі ППП, які розподіляють повноваження, обов'язки та ризики між публічними та приватними партнерами. Перш ніж зрозуміти, які 3 них найкраще зможуть підійти саме ППП щодо сталого розвитку сільських територій, проаналізуємо основні 3 них, для подальшого їх ефективного використання для кожного виду договірних відносин. Моделі ППП, в основному, розрізняються щодо власності на капітальні активи, відповідальності за інвестиції, прийнятті ризиків та тривалості договорів [31]. В основному моделі ППП використовуються для двох основних цілей: розробки нових об'єктів (наприклад, спорудження зрошувальних систем) та роботи над уже існуючими (наприклад, екологізація сільськогосподарських земель). Також моделі ППП можна розділити на проекти спрямовані на: проектування, будівництво або створення об'єктів та надання послуг.

Моделі публічно-приватного партнерства

\begin{tabular}{|c|c|}
\hline Типи моделей & Основні характеристики \\
\hline 1 & 2 \\
\hline 1. Finance Only (FO) & $\begin{array}{l}\text { Відповідно моделі “Тільки Фінансування” приватна ор- } \\
\text { ганізація, така як компанія фінансових послуг або банк, } \\
\text { фінансує будівництво державної інфраструктури безп- } \\
\text { середньо або за допомогоютакихмеханізмів, якдовгостро- } \\
\text { кова оренда або випуск облігацій. Державний партнер несе } \\
\text { всі ризики та витрати на будівництво та експлуатацію } \\
\text { об'єкта }\end{array}$ \\
\hline 2. Design-Bid-Build (DBB) & $\begin{array}{l}\text { Модель “Проектування-Пропозиція-Будівництво”. За цією } \\
\text { моделлю державний партнер визначає вимоги до проекту, } \\
\text { забезпечує його фінансування та проектування. Процедура } \\
\text { закупівлі використовується для вибору приватного учасн- } \\
\text { ка, відповідального за будівництво. Державний партнер є } \\
\text { власником нового побудованого об'єкта та забезпечує йо- } \\
\text { го обслуговування }\end{array}$ \\
\hline $\begin{array}{l}\text { 3. Design-Build-Maintain } \\
\text { (DBM) }\end{array}$ & $\begin{array}{l}\text { у моделі “Проектування-Будівництво-Обслуговування” } \\
\text { приватний партнер проектує, будує та підтримує інфра- } \\
\text { структуру відповідно до специфікацій та вимог публічного } \\
\text { партнера. Ціна, як правило, попередньо узгоджена і фік- } \\
\text { сована, тому ризики щодо вартості та забезпечення якості } \\
\text { та обслуговування побудованого об'єкта покладається на } \\
\text { приватного партнера. Державна установа володіє та екс- } \\
\text { плуатує активи }\end{array}$ \\
\hline
\end{tabular}


Продовження таблиці

\begin{tabular}{|c|c|}
\hline 1 & 2 \\
\hline 4. Operate-Maintain (OM) & $\begin{array}{l}\text { Модель “Експлуатація-Обслуговування". У цій моделі дер- } \\
\text { жавна установа підписує контракт з приватним партнером } \\
\text { про забезпечення або обслуговування сервісних функцій } \\
\text { через громадський заклад. Право власності на актив зали- } \\
\text { шається за публічним партнером. Іноді цю модель відно- } \\
\text { сять до аутсорсингових договорів }\end{array}$ \\
\hline 5. Operation License (OL) & $\begin{array}{l}\text { Згідно моделі “Операційна Ліцензія”, державний орган } \\
\text { надає ліцензію приватному суб’єкту господарювання для } \\
\text { надання державних послуг, як правило, з обмеженим тер- } \\
\text { міном дії. Ця модель часто використовується в IT-проектах }\end{array}$ \\
\hline $\begin{array}{l}\text { 6. Design-Build-Operate } \\
\text { (DBO) }\end{array}$ & $\begin{array}{l}\text { Модель “Проектування-Будівництво-Експлуатація”. У цій } \\
\text { моделі приватний партнер проектує та будує державне } \\
\text { майно відповідно до вимог та специфікації державного } \\
\text { партнера за фіксованою ціною. Державний суб’єкт несе } \\
\text { фінансування та витрати. Після завершення будівництва, } \\
\text { приватний партнер бере нерухомість в довгострокову } \\
\text { оренду для надання послуг }\end{array}$ \\
\hline $\begin{array}{l}\text { 7. Design-Build-Finance- } \\
\text { Operate (DBFO) }\end{array}$ & $\begin{array}{l}\text { Модель “Проектування-Будівництво-Фінансування-Екс- } \\
\text { плуатація”. За цією моделлю, приватний партнер проектує, } \\
\text { будує та фінансує новий державний об'єкт за довгостроко- } \\
\text { вою орендою. Протягом періоду оренди приватний парт- } \\
\text { нер експлуатує об'єкт, і після закінчення терміну дії об’єкт } \\
\text { передається державному партнеру }\end{array}$ \\
\hline $\begin{array}{l}\text { 8. Build-Own-Operate- } \\
\text { Transfer (BOOT) }\end{array}$ & $\begin{array}{l}\text { Модель “Будівництво-Володіння-Експлуатація-Передача”. } \\
\text { За цією моделлю приватний партнер розробляє, будує, фі- } \\
\text { нансує та керує державним об'єктом, зберігаючи при ць-- } \\
\text { му право власності за франшизою, наданою державним } \\
\text { суб'єктом. Приватний партнер стягує плату з державного } \\
\text { органу та / або кінцевих користувачів за надані послуги. } \\
\text { Наприкінці періоду франшизи право власності на об'єкт } \\
\text { передається назад державному партнеру без компенсації } \\
\text { приватному партнеру }\end{array}$ \\
\hline $\begin{array}{l}\text { 9. Lease-Develop-Operate } \\
\text { (LDO) }\end{array}$ & $\begin{array}{l}\text { Модель “Оренда-Розробка-Експлуатація”. Приватний } \\
\text { партнер орендує державний об’єкт, розробляє та вдоско- } \\
\text { налює його технологічно та функціонально, а також експлу- } \\
\text { атує його. Державний партнер зберігає право власності на } \\
\text { об'єкт і отримує платежі згідно договору оренди }\end{array}$ \\
\hline $\begin{array}{l}\text { 10. Build-Lease-Operate- } \\
\text { Transfer (BLOT) }\end{array}$ & $\begin{array}{l}\text { Модель “Будівництво-Оренда-Експлуатація-Передача”. } \\
\text { Приватний партнер створює та здає в оренду об'єкт, тоді } \\
\text { як право власності залишається за державним партнером. } \\
\text { Приватний партнер надає послуги і після закінчення тер- } \\
\text { міну дії договору право власності на об'єкт повертається } \\
\text { державному партнеру }\end{array}$ \\
\hline $\begin{array}{l}\text { 11. Buy-Own-Operate- } \\
\text { Transfer (BUYOOT) }\end{array}$ & $\begin{array}{l}\text { Модель “Купівля-Володіння-Експлуатація-Передача”. При- } \\
\text { ватний партнер купує державний об'єкт, використовує йо- } \\
\text { го протягом певного періоду часу та надає послугу. Після } \\
\text { закінчення терміну дії, за згодою, об’єкт передається дер- } \\
\text { жавному партнеру безкоштовно }\end{array}$ \\
\hline
\end{tabular}




\begin{tabular}{|l|l|}
\hline $\begin{array}{l}\text { 12. Design-Build-Finance- } \\
\text { Own-Operate-Transfer } \\
\text { (DBFOOT) }\end{array}$ & $\begin{array}{l}\text { Модель “Проектування-Будівництво-Фінансування-Воло- } \\
\text { діння-Експлуатація-Передача". у цій моделі приватний } \\
\text { партнер проектує, розробляє, будує та фінансує і реалізо- } \\
\text { вує публічний проект. Приватний партнер надає послуги та } \\
\text { користується об'єктом, який є його власністю, протягом } \\
\text { певного періоду часу. До закінчення терміну дії цього періо- } \\
\text { ду право власності передається державному партнеру без } \\
\text { компенсації }\end{array}$ \\
\hline $\begin{array}{l}\text { 13. Build-Own-Operate } \\
\text { (BOO) }\end{array}$ & $\begin{array}{l}\text { Модель “Будівництво-Володіння-Експлуатація”. Приват- } \\
\text { ний партнер створює та управляє державним майном, що } \\
\text { перебуває у їх власності, без зобов'язання передавати ак- } \\
\text { тиви державномупартнеру. Державний партнер регулює та } \\
\text { контролює якість послуг, що надаються приватним партне- } \\
\text { ром }\end{array}$ \\
\hline $\begin{array}{l}\text { 14. Buy-Build-Оретате } \\
\text { (ВВО) }\end{array}$ & $\begin{array}{l}\text { у моделі “Купівля-Будівництво-Експлуатація”, приватний } \\
\text { партнер купує державний об'єкт за домовленістю про те, } \\
\text { що активи повинні модернізуватися та експлуатуватися } \\
\text { протягом певного періоду часу. Приватний партнер також } \\
\text { надає послуги державному партнеру та/або кінцевим ко- } \\
\text { ристувачам. Після закінчення строку приватний партнер } \\
\text { зберігає право власності на державний актив }\end{array}$ \\
\hline
\end{tabular}

Джерело: Складено на основі даних Керівництва, щодо публічно-приватного партнерства в державному управлінні, Європейської економічної комісії ООН [31].

В даній таблиці приведені основні типи моделей співпраці між державними та приватними партнерами, але види моделей можуть змінюватися та доповнюватися, та в основі всіх моделей лежить визначення основних параметрів співпраці: розподіл обов'язків та ризиків між державними та приватними партнерами. Кожна 3 моделей має свої переваги і недоліки, тому потрібно враховувати всі ризики та можливості при застосуванні у кожному конкретному випадку, щоб отримати найбільшу користь для держави або громади. Насамперед, потрібно визначитись з видом прав на управління державним або комунальним об'єктом (користування, володіння, експлуатація, придбання, створення, будівництво, реконструкція, модернізація), визначитись 3 розподілом частини ризиків, умови фінансування та залучення інвестицій. Публічно-приватне партнерство - це угода про співпрацю між двома або більше державними та приватними партнерами, як правило, довгострокового характеру (від 5 до 50 років), щодо об’єктів державної та комунальної власності. У рамках здійснення ППП можуть укладатися: концесійний договір, договір управління майном (виключно за умови передбачення у договорі, укладеному в рамках державно-приватного партнерства, інвестиційних зобов'язань приватного партнера), договір про спільну діяльність та інші договори (ст. 5. ЗУ "Про державно-приватне партнерство” [32].

Наступні елементи характеризують ППП:

- Відносно тривалий строк співпраці між державним та приватним 
партнером щодо різних аспектів запланованого проекту;

- Форма фінансування проекту, частково з приватного сектору, іноді за рахунок додаткових інвестицій/ додаткове залучення бюджетних коштів;

- Важлива роль приватного інвестора, який бере участь у різних етапах в проекті (проектування, будівництво, реалізація, фінансування та ін.). Державний партнер зосереджується, в першу чергу, на визначенні цілей, яких слід досягти з точки зору, інтересу громади, якості наданих послуг, цінової політики, контролює і несе відповідальність за дотриманням цих цілей;

- Розподіл ризиків між публічним та приватним партнерами. Однак, точний розподіл ризиків визначається в кожному конкретному випадку відповідно до можливостей зацікавлених сторін, в будь-якому разі державний сектор зберігає відповідальність за надання цих послуг населенню таким чином, що приносить користь громадськості та забезпечує економічний розвиток та поліпшення якості життя громадян.

В Керівництві з розвитку публічно-приватного партнерства Європейської економічної комісії ООН, визначені основні принципи належного управління [31]: Участь; Порядність; Прозорість; Підзвітність; Чесність; Ефективність; Сталий розвиток.

В Україні, організаційно-правовими засадами реалізації співпраці між державними партнерами 3 приватними інвесторами, які визначають основні принципи державно-приватного партнерства визначені в на- ступних нормативно-правових актах України: ЗУ “Про державно-приватне партнерство” від 01.07.2010 № 2404-VI [32]; 3У “Про концесію” від 03.10.2019 № 155-IX [33]; Підзаконні нормативно-правові акти, що регулюють здійснення ППП: Постанова КМУ від 11.04.2011 № 384 “Деякі питання організації здійснення державно-приватного партнерства" [34]; Постанова КМУ від 16.02.2011 № 232 “Про затвердження Методики виявлення ризиків здійснення державно-приватного партнерства, їх оцінки та визначення форми управління ними" [35]; Наказ Міністерства економічного розвитку і торгівлі України від 27.02.2012 № 255 “Деякі питання проведення аналізу ефективності здійснення державно-приватного партнерства" [36]; Наказ Міністерства розвитку економіки, торгівлі та сільського господарства України від 26.05.2020 № 986 “Про затвердження Порядку подання державними партнерами (концесієдавцями) щорічного звіту про виконання договору, укладеного в рамках державно-приватного партнерства, у тому числі концесійного договору" від 06.07.2020 № 628/34911 [37]; Постанова КМУ від 01.07.2020 № 541 “Про затвердження Порядку заміни приватного партнера (концесіонера) за договором, укладеним в рамках державно-приватного партнерства (концесійним договором)" [38]; Постанова КМУ від 22.07.2020 № 621 “Про затвердження Порядку повернення концесієдавцю об’єкта концесії після припинення дії концесійного договору" [39]. Нормативно-правові засади ППП також визначені в Господарському кодексі України та Ци- 
вільному кодексі України (поняття та умови договорів).

Публічно-приватне партнерство в сфері сталого розвитку сільських територіальних громад - це рівноправне і взаємовигідне співробітництво між державою, об'єднаними територіальними громадами (в особі відповідних органів державної влади чи місцевого самоврядування) та приватним сектором з метою ефективного використання ресурсних можливостей територіальної громади та залучення інвестицій, інновацій та технологій приватних інвесторів для реалізації соціально-економічних проектів, важливих для забезпечення сталого розвитку сільських територій і розвитку соціально-економічного потенціалу громади.

В ЗУ "Про державно-приватне партнерство”, сфера сільськогосподарського виробництва не врахована взагалі, окрім забезпечення функціонування зрошувальних і осушувальних систем, тільки в частині другій наголошується на можливості застосування ППП в інших сферах діяльності. Потребує також роз'яснення в законодавстві України можливість та механізм використання земельних ділянок сільськогосподарського призначення для здійснення ППП. Для сільських територій сільськогосподарські землі - це основний виробничий актив, а з проведенням масштабної земельної реформи та передачі земель сільськогосподарського призначення державної власності об'єднаним територіальним громадам в комунальну власність, постає питання перед громадами сіл щодо ефективного використання та охорони земель. Ефективне управ- ління таким масивом земель потребує зусиль як від місцевих органів влади, так і безпосередньої участі громадян. 3 метою покращення стану деградованих або малопродуктивних земель, ефективним інструментом є механізм публічно-приватного партнерства. Так, в сфері земельних відносин, можна виділити наступні пріоритетні заходи щодо здійснення ППП: екологізація сільськогосподарських земель; проведення заходів меліорації, щодо відновлення деградованих та малопродуктивних земель; спорудження зрошувальних систем та ін. 3 цією метою здійснення ППП буде досить ефективним, адже земля надається в довгострокове користування до 50 років, з чітко визначеними вимогами, які набувач прав користування земельною ділянкою повинен виконати. Так, наприклад, здійснення заходів щодо відновлення родючості грунтів на малопродуктивних та деградованих землях, можна представити за такою моделлю, публічний партнер надає об'єкт ППП - земельну ділянку, визначає чітко вимоги до користувача, на строк до 50 років, останній сплачує орендну плату, після якого ділянка повертається публічному партнеру. За цією моделлю публічний партнер отримує вигоду від того, що якість грунту покращується за рахунок здійснення заходів меліорації приватним партнером, який, натомість отримує ділянку в оренду, з можливістю розстрочки орендної плати по закінченню заходів по відновленню грунтів, і з правом подальшого використання сільськогосподарської землі для здійснення господарської діяльності і для повернення інвести- 
цій та отримання прибутку. Враховуючи роль землі для сільської громади, яка є територіальним базисом та основним виробничим засобом, право комунальної власності на сільськогосподарську землю сільської територіальної громади повинно за нею залишатись, а приватний партнер може мати права користування земельною ділянкою, при цьому громада здійснює постійний моніторинг за виконанням всіх вимог приватним партнером. В міжнародній практиці для використання земельних ділянок сільськогосподарського призначення в якості об'єкта ППП найбільше підходить модель: LeaseDevelop-Operate (LDO) - Модель "Оренда-Розробка-Експлуатація", за якою приватний партнер орендує державний об'єкт, розробляє та вдосконалює його технологічно та функціонально, а також експлуатує його. Державний партнер зберігає право власності на об'єкт і отримує платежі згідно договору оренди. В основному в проектах ППП укладається концесійний договір між концесіонером та концесієдавцем, який визначає порядок та умови реалізації проекту, що здійснюється на умовах концесії. Згідно із п. 11 ст. 1 ЗУ “Про Концесію” концесія - форма здійснення державно-приватного партнерства, що передбачає надання концесієдавцем концесіонеру права на створення та/або будівництво (нове будівництво, реконструкцію, реставрацію, капітальний ремонт та технічне переоснащення), та/або управління (користування, експлуатацію, технічне обслуговування) об'єктом концесії, та/або надання суспільно значущих послуг у порядку та на умовах, визначених концесійним договором, а також передбачає передачу концесіонеру переважної частини операційного ризику, що охоплюе ризик попиту та/або ризик пропозиції [33]. В Законі також визначено строк, на який укладається концесійний договір він має становити не менше п'яти років та не більше 50 років, крім строку концесійного договору щодо будівництва та подальшої експлуатації автомобільних доріг, який має становити не менше 10 років. На строк договору впливає строк експлуатації об'єкта концесії та його амортизація, строк окупності інвестицій і термін необхідний для досягнення цілей проекту концесії.

Іншими досить важливими сферами щодо розвитку сільських територій до яких можуть буди залучені приватні партнери, наступні: 1) будівництво водоочищувальних систем, із застосуванням новітніх технологій, спорудження водопровідних та каналізаційних систем і наданням подальших послуг по водопостачанню для населення (в даних проектах використовується модель - LDO); 2) спорудження інфраструктурних об'єктів, таких як аграрні ринки для збуту сільськогосподарської продукції та оптової торгівлі (може застосовуватись модель - DBO); 3) розвиток сільського туризму, проведення різноманітних культурних заходів (модель ППП - ОМ); 4) будівництво сміттєперероблювальних об'єктів, 3 їх наступною експлуатацією (DBO); 5) надання соціальних послуг, управління соціальною установою, закладом (OM; OL); 6) виробництво та впровадження енергозберігаючих технологій (DBFO); 7) будівництво 
та капітальний ремонт житлових будинків (DBB).

Іншою не менш важливою сферою, в якій необхідна активна участь держави та приватного сектора економіки - це страхування аграрних ризиків. Аграрний сектор - це найбільш ризикований вид господарської діяльності, на нього впливають різноманітні природні чинники (посуха, заморозки, буревії, повені та ін.), які не піддаються прогнозуванню та людському впливу. Не менш катастрофічними можуть бути фінансово-економічні ризики, наприклад, падіння ціни на сільськогосподарську продукцію. У багатьох розвинених країнах світу саме агрострахування є захистом від ризиків втрати врожаю, та падіння ціни. В Україні, агрострахування не дуже поширене, на це впливають: висока вартість агрострахування, недовіра до страхових компаній, відсутність державної підтримки та зацікавленості в розвитку аграрного страхування. Відповідно до моделей ППП, для агрострахування можна використовувати наступні моделі: Finance Only (FO), Operate-Maintain (OP), Operation License (OL). За моделлю FO приватна організація, як правило, компанія фінансових послуг, фінансує проект безпосередньо або використовує різні механізми, такі як довгострокова оренда або випуск облігацій, держава, в цьому разі, бере на себе всі або частину ризиків і витрат. Згідно із моделлю ОМ: приватний оператор за контрактом експлуатує державний актив протягом визначеного терміну (так званий договір аутсорсингу - передача однією компанією певних функцій та завдань на виконання іншій, яка спеціалізується у відповідній галузі). Право власності на актив залишається за державою. Хоча, існує думка, що модель ОМ не належать до спектру договорів про ППП, а такі контракти розглядаються як контракти на послуги. Ще однією можливою моделлю співпраці в даній сфері може бути модель OL (Операційна Ліцензія), за якою державний орган надає ліцензію приватному суб'єкту господарювання для надання державних послуг.

Даними моделями співпраця в ППП не обмежується, адже 3 невпинним розвитком економічних відносин, змінюються і умови співпраці ППП, але єдине, що повинно відрізняти звичайні договори про надання послуг чи інших бізнесових контрактів, - це те, що в рамках публічно-приватного партнерства повинні досягатись, насамперед, соціально-економічні та екологічні цілі, які впливають на покращення якості життя громадян України. Державний сектор, в свою чергу, контролює якість надання послуг громадськості, вирішення проблем в сільських громадах, а також несе відповідальність за ефективність реалізації публічно-приватної співпраці.

Висновки. Дана форма взаємного партнерства має досить вагомі переваги щодо управління державним та комунальним майном. Завдяки механізму ППП:

- в рази підвищується ефективність управління об'єктами державної та комунальної власності;

- покращується якість надання публічних послуг;

- використовуються новітні технології та інновації; 
- запроваджуються новітні методи управління, що підвищує рівень ефективності прийнятих рішень;

- знижуються видатки державного та місцевого бюджетів на утримання бюджетних установ та об'єктів;

- розподіляються ризики між державним та приватним партнерами;

- підвищується рівень ефективності реалізованих проектів завдяки взаємному контролю та моніторингу, тим самим зникають можливі корупційні складові;

- підвищується довіра до проектів, з боку міжнародної спільноти, якщо в ньому бере участь держава або місцева влада, з одного боку, та приватний партнер, з іншого, що відкриває доступ до вигідних міжнародних фінансових інструментів.

Бюджетів сільських громад недостатньо для вирішення всіх проблем одночасно, тому саме механізм залучення приватних інвесторів на умовах публічно-приватного партнерства може стати засобом їх вирішення. Для того, щоб даний механізм запрацював, потрібно: органам виконавчої влади проводити масштабні консультування представників органів місцевого самоврядування; надати можливості приватним партнерам робити свої пропозиції щодо об'єктів ППП місцевій владі; широко застосовувати несільськогосподарські види діяльності (розвиток енергозберігаючих технологій, легку промисловість та ін.); законодавчо визначити в ЗУ "Про державно-приватне партнерство” сфери сільськогосподарської діяльності; в Законі потрібно визначити умови залучення земель сільськогосподарського призначення на умовах ППП (наприклад, передача деградованих та малопродуктивних сільськогосподарських земель приватному партнеру на договорі концесії, так званої довгострокової оренди із визначенням умов використання та покращення якості грунту, при цьому право власності на сільськогосподарську ділянку залишається за місцевою владою) (адже в ст. 8. Використання земельних ділянок для здійснення державно-приватного партнерства, передбачені лише умови отримання приватним партнером земельних ділянок та/або прав на них під забудову); запровадити механізми публічно-приватної співпраці в сфері аграрного страхування, на основі розподілу фінансування та ризиків з приватним партнером. Загалом, ми можемо виділити чотири основні сфери діяльності публічно-приватного партнерства щодо розвитку сільського господарства та сталого розвитку сільських територій:

1. Сфера земельних відносин (заходи меліорації, охорони земель, спорудження зрошувальних систем, екологізація сільськогосподарських земель та ін.);

2. Сфера будівництва нових інфраструктурних об'єктів або поліпшення вже збудованих (удосконалення інженерних мереж та забезпечення розвитку соціальної інфраструктури, системи каналізації та водопостачання);

3. Сфера надання послуг громаді (освіта, спорт, рекреація, туризм, культура);

4. Сфера аграрного страхування.

Таким чином, використання механізму публічно-приватного партнерства в сфері земельних відносин, 
інфраструктурних проектів, наданні послуг та аграрному страхуванні дає можливість об'єднати ресурси та фінансування держави, місцевої громади та приватних партнерів, внаслідок чого досягаються кращі соціальноекономічні результати, ефективніше використовуються державні та комунальні ресурси і майно, запроваджуються інновації, передові технології, а також новітні системи управління, а саме головне досягаються цілі сталого розвитку сільських громад та аграрного сектору економіки.

\section{СПИСОК ВИКОРИСТАНИХ ДЖЕРЕЛ}

1. Про схвалення Концепції розвитку сільських територій: Розпорядження Кабінету Міністрів України; Концепція від 23.09.2015 р. № 995-p. URL: https://zakon. rada.gov.ua/laws/show/995-2015$\% \mathrm{D} 1 \% 80$ \# Text.

2. Глеба В. Ю. Просторово-адміністративна організація міста Києва та архетипи територій // Публічне управління: теорія та практика. Х.: Вид-во “Док. наук. держ. упр”. 2013.

3. Ковінчук O. Архетип території та його вплив на кластери в реалізації державної політики розвитку територій // Публічне управління: теорія та практика. 2015. Вип. 1 (спец. вип.). С. 116-122. URL: http://nbuv.gov.ua/UJRN/ Pubupr_2015_1\%28spets._21

4. Афонін Е., Плахтій T. Архетипіка і публічне управління: стратегії сталого розвитку в умовах цивілізаційних зрушень / / Український соціум. 2019. № 2 (69). С. 142-151.

5. Макарова А. Архетип як предмет досліджень у сучасній українській гуманітаристиці / / Гілея: наук. вісник. 2020. № 152 (1). С. 171-176.
6. Макарова А. Архетипний підхід у сучасних українських дослідженнях соціальної діяльності: досвід української школи архетипіки // Гуманітарні візії. Львів : Вид-во Львівської політехніки, 2020. Т. 6. № 1. C. 54-59. URL: https://doi org/10.23939/shv2020.01.054

7. Бистряков І. К., Клиновий Д. В. Проблематика імплементації європейських публічно-приватних форматів сталого господарювання в Україні // Економіка природокористування і сталий розвиток. К.: ДУ ІЕПСР НАН України. 2019. № 5 (24). C. 14-20.

8. Степаненко А. В., Омельченко А. А. Форми публічно-приватного партнерства в системі гарантування природно-техногенної та екологічної безпеки // Економіка природокористування і сталий розвиток. К.: ДУ ІЕПСР НАН України, 2019. № 5 (24). С. 34-40.

9. Третяк Н. А., Каленська О. В. Використання світового досвіду публічно-приватного партнерства в Україні // Економіка природокористування і сталий розвиток. К.: ДУ ІЕПСР НАН України, 2019. № 5 (24). C. 41-47.

10. Rankin M., Nogales G., Santacoloma P., Mhlanga N., Rizzo C. Public-private partnerships for agribusiness development - A review of international experiences, FAO. 2016. Rome, Italy. URL: $\quad$ http://www.fao.org/3/ai5699e.pdf

11. Hermans F., Geerling-Eiff F., Potters J., Klerkx L. Public-private partnerships as systemic agricultural innovation policy instruments - Assessing their contribution to innovation system function dynamics, NJAS // Wageningen Journal of Life Sciences. 2019, Vol. 88, P. 76-95. URL: http://dx.doi.org/10.1016/j. njas.2018.10.001. http://www.sci- 
encedirect.com/science/article/pii/ S1573521418300332

12. Romero M. What lies beneath? A critical assessment of PPPs and their impact on sustainable development. 2015. URL: https://www.eurodad. org/what lies_beneath.

13. Caldwell N., Roehrich J., George G. Social Value Creation and Relational Coordination in Public-Private Collaborations // Journal of Management Studies. 2017.Vol. 54. Is. 6. P. 906-928. URL: doi:10.1111/ joms.12268.

14. Статівка А. М., Кульчій I. М. Публічно-приватне партнерство у сфері розвитку сільських територій. Проблеми правового забезпечення сталого розвитку сільських територій в Україні: монографія / за ред. А. П. Гетьмана та М. В. Шульги. Харків: Право, 2016. С. 137-154.

15. Кульчій I. М. Публічно-приватне партнерство як спосіб забезпечення сталого розвитку сільських територій // Проблеми законності. 2017. Вип. 138. C. 99-108.URL: doi: 10.21564/2414-990x.138.108564

16. Онегіна В. М., Батюк Л. А. Державно-приватне партнерство та розвиток сільських територій в Україні // Актуальні пробл. інноваційної економіки. 2017. № 2. С. 64-71.

17. Кальна-Дубінюк Т. П. Соціальне партнерство в сільській місцевості 3 використанням потенціалу дорадчих служб / Т. П. Кальна-Дубінюк, М. В. Бесчастна // Економіка АПК. 2015. № 7. С. 71-76. URL: http://nbuv.gov.ua/UJRN/E_ apk_2015_7_11

18. Жавнерчик O. В. Механізм державно-приватного партнерства в сфері екологізації сільськогосподарського землекористування // Економічні інновації. 2016. Вип. 61. С. 114-123. URL: http://nbuv.gov.ua/UJRN/ ecinn_2016_61_13
19. Кулинии П. Ф. Земельно-правові аспекти розвитку сільськогосподарської кооперації в Україні на засадах публічно-приватного партнерства: шляхи вдосконалення // Часопис Київського ун-ту права. 2014. № 1. С. 247-251. URL: http://nbuv.gov.ua/UJRN/ Chkup_2014_1_58

20. Кропивко М. $\Phi$. Напрями удосконалення державного управління аграрним сектором в умовах децентралізації влади та дерегуляції господарської діяльності / М. Ф. Кропивко, М. М. Ксенофонтов, Н. В. Хміль // Економіка АПК. 2015. № 3. C. 5-14. URL: http://nbuv.gov. ua/UJRN/E apk 20153 3Literature

21. Kozin M., Pyrchenkova G. and Radchenko E. Public-private partnership in the agricultural sector: empirical estimation by factorial characteristics. XIII International Scientific and Practical Conference "State and Prospects for the Development of Agribusiness - INTERAGROMASH 2020". Volume 175, 2020. URL: https://doi. org/10.1051/e3sconf/202017513016

22. Shylepnytskyi $P$. The Role of the Public-Private Partnership in Local Development. Agricultural Economics and Rural Development. - Institute of Agricultural Economics, 2017. vol. 14(2), P. 209-216. URL: https:// ideas.repec.org/a/iag/reviea/v14y2017i2p209-216.html

23. Шашула Л. О., Денисенко I. С. Публічно-приватне партнерство у сфері землекористування: форми забезпечення та характеристики // Економіка природокористування і сталий розвиток. К.: ДУ ІЕПСР НАН України. 2019. № 5 (24). C. 96-102. URL: http://ecops.kiev. ua/files/2019(5)/18.pdf

24. Танклевська Н. С., Ярмоленко В. В. Перспективи адаптації зарубіжного досвіду агрострахування в Украї- 
ні // Економіка харчової промисловості. 2020. Т. 12, вип. 1. С. 55-63. URL: doi: 10.15673/fie.v12i1.1669

25. третяк К. В. Агрострахування: Зарубіжний досвід та ресурси щодо його імплементації в українську страхову практику // Ефективна економіка. 2019. №1. URL: doi: 10.32702/2307-2105-2019.1.32

26. Шипшанова Н. О., Совщак С. С., Мельник Ю. В. Зарубіжний довід аграрного страхування та можливості його впровадження у вітчизняну страхову практику // Гроші, фінанси і кредит. 2018. Вип. 22. С. 872876. URL: http://global-national. in.ua/archive/22-2018/164.pdf

27. Стельмашук A. M. Формування ринкової моделі агрострахування на засадах державно-приватного партнерства // Інноваційна економіка. 2019. C. 13-24. URL: http://inneco. org/index.php/innecoua/article/ view $/ 4 / 5$

28. Report of the World Commission on Environment and Development: Our Common Future. URL: https://sustainabledevelopment.un.org/content/ documents/5987our-common-future. pdf

29. Public-Private Partnerships and the 2030 Agenda for Sustainable Development: Fit for purpose? DESA Working Paper No. 148ST/ESA/2016/ DWP/148 February 2016. URL: https://www.un.org/esa/desa/papers/2016/wp148_2016.pdf.

30. Green Paper on public-private partnerships and Community law on public contracts and concessions (presented by the Commission), 2004. URL: http://eur-lex. europa.eu/legal-content/EN/ TXT/?uri=celex:52004DC0327.

31. United Nations Economic Commission for Europe. Guidebook on Promoting Good Governance in Public-Private Partnerships. United Na- tions, New York and Geneva, 2008. URL: https://www. unece.org/fileadmin/DAM/ceci/publications/ppp. pdf.

32. Про державно-приватне партнерство: Закон України від 01.07.2010 р. № 2404-VI. URL: https://zakon.rada. gov.ua/laws/show/2404-17\#Text

33. Про концесію: Закон України "Про концесію” від 03.10.2019 р. № 155IX. URL: ttps://zakon.rada.gov.ua/ laws/show/155-20\#Text

34. Деякі питання організації здійснення державно-приватного партнерства Постанова Кабінету Міністрів України; Порядок від 11.04.2011 р. № 384. URL: https://zakon.rada. gov.ua/laws / show/384-2011$\% \mathrm{D} 0 \% \mathrm{BF} \# \mathrm{Text}$

35. Про затвердження Методики виявлення ризиків здійснення державно-приватного партнерства, їх оцінки та визначення форми управління ними Постанова Кабінету Міністрів України; Методика, Форма типового документа, Перелік від 16.02.2011 p. № 232. URL: https:// zakon.rada.gov.ua/laws/show/2322011-\%D0\%BF\#Text

36. Деякі питання проведення аналізу ефективності здійснення державноприватного партнерства Мінекономрозвитку України; Наказ, Форма, Методика [...] від 27.02.2012 № 255. URL: https://zakon.rada.gov. ua/laws/show/z0399-12\#Text

37. Про затвердження Порядку подання державними партнерами (концесієдавцями) щорічного звіту про виконання договору, укладеного в рамках державно-приватного партнерства, [...] Мінеконом, торгівлі та сг; Наказ, Порядок, Форма [...] від 26.05.2020 p. № 986. URL: https:// zakon.rada.gov.ua/laws/show/z062820\#Text

38. Про затвердження Порядку заміни приватного партнера (концесіонера) 
за договором, укладеним в рамках державно-приватного партнерства (концесійним договором) Постанова Кабінету Міністрів України; Порядок від 01.07.2020 р. № 541. URL:https://zakon.rada.gov.ua/laws/ show $/ 541-2020-\%$ D0\%BF\#Text

39. Про затвердження Порядку повернення концесієдавцю об'єкта концесії після припинення дії концесійного договору Постанова Кабінету Міністрів України; Порядок від 22.07.2020 p. № 621. URL: https:// zakon.rada.gov.ua/laws/show/6212020-\%D0\%BF\#Text

\section{REFERENCES}

1. Rozporiadzhennia Kabinetu Ministriv Ukrainy "Pro skhvalennia Kontseptsii rozvytku silskykh terytorii": vid 23.09.2015 № 995-r [Order of the Cabinet of Ministers of Ukraine "On approval of the Concept of rural development" from 23.09.2015, № 995-r].zakon.rada.gov.ua. Retrieved from https://zakon.rada.gov.ua/laws/ show/995-2015-\%D1\%80\#Text [in Ukrainian].

2. Hleba V. Yu. (2013). Prostorovoadministratyvna orhanizatsiia mista Kyieva ta arkhetypy terytorii [Spatialadministrative organization of the city of Kyiv and archetypes of territories]. Publichne upravlinnia: teoriia ta praktyka - Public administration: theory and practice, 3-4, 26-32 [in Ukrainian].

3. Kovinchuk O. (2015). Arkhetyp terytorii ta yoho vplyv na klastery $\mathrm{v}$ realizatsii derzhavnoi polityky rozvytku terytorii [Archetype of the territory and its impact on clusters in the implementation of state policy of territorial development]. Publichne upravlinnia: teoriia ta praktyka - Public administration: theory and practice, 1, 116-122. Retrieved from http://nbuv.gov.ua/UJRN/
Pubupr_2015_1\%28spets._21 [in Ukrainian].

4. Afonin E., Plakhtii T. (2019). Arkhetypika i publichne upravlinnia: stratehii staloho rozvytku v umovakh tsyvilizatsiinykh zrushen [Archetypes and public administration: strategies for sustainable development in the context of civilizational changes]. Ukrainskyi sotsium - Ukrainian Society, 2(69), 142-151 [in Ukrainian].

5. Makarova A. (2020). Arkhetyp yak predmet doslidzhen $u$ suchasnii ukrainskii humanitarystytsi [Archetype as a subject of research in modern Ukrainian humanities]. Hileia - Gilea, 152(1), 171-176 [in Ukrainian].

6. Makarova A. (2020). Arkhetypnyi pidkhid u suchasnykh ukrainskykh doslidzhenniakh sotsialnoi diialnosti: dosvid ukrainskoi shkoly arkhetypiky [Archetypal approach in modern Ukrainian studies of social activity: the experience of the Ukrainian school of archetypes]. Humanitarni vizii - Humanitarian visions, 6(1), 54-59. Retrieved from https://doi. org/10.23939/shv2020.01.054 [in Ukrainian].

7. Bystriakov I. K., Klynovyi D. V. (2019). Problematyka implementatsii yevropeiskykh publichno-pryvatnykh formativ staloho hospodariuvannia $\mathrm{v}$ Ukraini [Problems of implementation of European public-private formats of sustainable management in Ukraine]. Ekonomika pryrodokorystuvannia $i$ stalyi rozoytok - Environmental Economics and Sustainable Development, 5(24), 14-20 [in Ukrainian].

8. Stepanenko A. V., Omelchenko A. A. (2019). Formy publichno-pryvatnoho partnerstva $\mathrm{v}$ systemi harantuvannia pryrodno-tekhnohennoi ta ekolohichnoi bezpeky [Forms of public-private partnership in the system of guaranteeing natural and man-made and environmental safety]. Ekonomika 
pryrodokorystuvannia $i$ stalyi rozvytok - Environmental Economics and Sustainable Development, 5(24), 3440 [in Ukrainian].

9. Tretiak N. A., Kalenska O. V. (2019). Vykorystannia svitovoho dosvidu publichno-pryvatnoho partnerstva $\mathrm{v}$ Ukraini [Using the world experience of public-private partnership in Ukraine]. Ekonomika pryrodokorystuvannia $i$ stalyi rozoytok - Environmental Economics and Sustainable Development, 5(24), 41-47 [in Ukrainian].

10. Rankin M., Nogales G., Santacoloma P., Mhlanga N., Rizzo C. (2016). Public-private partnerships for agribusiness development $-A$ review of international experiences, FAO. Rome: Food and Agriculture Organization of the United Nations. Retrieved from http://www.fao.org/3/a-i5699e.pdf [in English].

11. Hermans F., Geerling-Eiff F., Potters J., Klerkx L. (2019). Public-private partnerships as systemic agricultural innovation policy instruments Assessing their contribution to innovation system function dynamics. NJAS - Wageningen Journal of Life Sciences, 88, 76-95. Retrieved from http://dx.doi.org/10.1016/j. njas.2018.10.001. http://www.sciencedirect.com/science/article/pii/ S1573521418300332 [in English].

12. Romero M. (2015). What lies beneath? A critical assessment of PPPs and their impact on sustainable development. wrere.eurodad.org. Retrieved from https://www.eurodad.org/ what_lies_beneath [in English].

13. Caldwell N̄., Roehrich J., George G. (2017). Social Value Creation and Relational Coordination in PublicPrivate Collaborations. Journal of Management Studies, 54(6), 906928. Retrieved from doi:10.1111/ joms.12268 [in Ukrainian].
14. Stativka A. M., Kulchii I. M. (2016). Publichno-pryvatne partnerstvo $u$ sferi rozvytku silskykh terytorii [Public-private partnership in the field of rural development]. A. P. Hetman, M. V. Shulhy (Eds.). Problemy pravovoho zabezpechennia staloho rozoytku silskykh terytorii v Ukraini - Problems of legal support for sustainable development of rural areas in Ukraine. (p. 137-154). Kharkiv: Pravo [in Ukrainian].

15. Kulchii I. M. (2017). Publichno-pryvatne partnerstvo yak sposib zabezpechennia staloho rozvytku silskykh terytorii [Public-private partnership as a way to ensure sustainable development of rural areas]. Problemy zakonnosti - Problems of legality, 138, 99-108. Retrieved from http://plaw. nlu.edu.ua/article/view/108564 [in Ukrainian].

16. Onehina V. M., Batiuk L. A. (2017). Derzhavno-pryvatne partnerstvo ta rozvytok silskykh terytorii $\mathrm{v}$ Ukraini [Public-private partnership and development of rural areas in Ukraine]. Aktualni problemy innovatsiinoi ekonomiky - Actual problems of innovative economy, 2, 64-71 [in Ukrainian].

17. Kalna-Dubiniuk T. P., Beschastna M. V. (2015). Sotsialne partnerstvo v silskii mistsevosti z vykorystanniam potentsialu doradchykh sluzhb [Social partnership in rural areas with the use of the potential of advisory services]. Ekonomika APK - The Economy of Agro-Industrial Complex, 7, 71-76. Retrieved from http://nbuv. gov.ua/UJRN/E_apk_2015_7_11 [in Ukrainian].

18. Zhavnerchyk O. V. (2016). Mekhanizm derzhavno-pryvatnoho partnerstva v sferi ekolohizatsii silskohospodarskoho zemlekorystuvannia [The mechanism of public-private partnership in the field of greening of agricultural land use]. Ekonomichni innovat- 
sii - Economic innovations, 61, 114123. Retrieved from http://nbuv.gov. ua/UJRN/ecinn_2016_61_13 [in Ukrainian].

19. Kulynych P. F. (2014). Zemelno-pravovi aspekty rozvytku silskohospodarskoi kooperatsii v Ukraini na zasadakh publichno-pryvatnoho partnerstva: shliakhy vdoskonalennia [Land and legal aspects of agricultural cooperation in Ukraine on the basis of publicprivate partnership: ways to improve]. Chasopys Kyizskoho universytetu prava - Journal of Kyiv University of Laze, 1, 247-251. Retrieved from http://nbuv.gov.ua/UJRN/ Chkup_2014_1_58 [in Ukrainian].

20. Kropyvko M. F., Ksenofontov M. M., Khmil N. V. (2015). Napriamy udoskonalennia derzhavnoho upravlinnia ahrarnym sektorom v umovakh detsentralizatsii vlady ta derehuliatsii hospodarskoi diialnosti [Directions for improving public administration of the agricultural sector in terms of decentralization of power and deregulation of economic activity]. Ekonomika APK - The Economy of AgroIndustrial Complex, 3, 5-14. Retrieved from http://nbuv.gov.ua/UJRN/E apk_2015_3_3Literature [in Ukrainian].

21. Kozin M., Pyrchenkova G., Radchenko E. (2020). Public-private partnership in the agricultural sector: empirical estimation by factorial characteristics. State and Prospects for the Development of Agribusiness - INTERAGROMASH 2020 : Proceedings of $13^{\text {th }}$ International Scientific and Practical Conference. (Vol. 175). Retrieved from https://www.e3s-conferences. org/articles/e3sconf/pdf/2020/35/ e3sconf_interagromash2020_13016. pdf [in English].

22. Shylepnytskyi P. (2017). The Role of the Public-Private Partnership in Local Development. Agricultural Eco- nomics and Rural Development, Institute of Agricultural Economics, 14(2), 209-216. Retrieved from https:// ideas.repec.org/a/iag/reviea/v14y2017i2p209-216.html [in Ukrainian].

23. Shashula L. O., Denysenko I. S. (2019). Publichno-pryvatne partnerstvo u sferi zemlekorystuvannia: formy zabezpechennia ta kharakterystyky [Public-private partnership in the field of land use: forms of provision and characteristics]. Ekonomika pryrodokorystuvannia $i$ stalyi rozvytok Environmental Economics and Sustainable Development, 5(24), 96-102. Retrieved from http://ecops.kiev.ua/ files/2019(5)/18.pdf [in Ukrainian].

24. Tanklevska N. S., Yarmolenko V. V. (2020). Perspektyvy adaptatsii zarubizhnoho dosvidu ahrostrakhuvannia v Ukraini [Prospects for adaptation of foreign experience of agricultural insurance in Ukraine]. Ekonomika kharchovoi promyslovosti - Economics of food industry, 12(1), 55-63. DOI: 10.15673/fie.v12i1.1669 [in Ukrainian].

25. Tretiak K. V. (2019). Ahrostrakhuvannia: Zarubizhnyi dosvid ta resursy shchodo yoho implementatsii v ukrainsku strakhovu praktyku [Agroinsurance: Foreign experience and resources for its implementation in Ukrainian insurance practice]. Efektyona ekonomika - Effective Economics, 1. Retrieved from http://www.economy. nayka.com.ua/ $\mathrm{op}=1 \& \mathrm{z}=6828 \mathrm{DOI}$ : 10.32702/2307-2105-2019.1.32 [in Ukrainian].

26. Shypshanova N. O., Sovshchak S. S., Melnyk Yu. V. (2018). Zarubizhnyi dovid ahrarnoho strakhuvannia ta mozhlyvosti yoho vprovadzhennia $\mathrm{u}$ vitchyznianu strakhovu praktyku [Foreign proof of agricultural insurance and the possibility of its introduction into domestic insurance practice]. Hroshi, finansy $i$ kredyt - Money, fi- 
nance and credit, 22, 872-876. Retrieved from http://global-national. in.ua/archive/22-2018/164.pdf [in Ukrainian].

27. Stelmashchuk A. M. (2019). Formuvannia rynkovoi modeli ahrostrakhuvannia na zasadakh derzhavno-pryvatnoho partnerstva [Formation of a market model of agricultural insurance on the basis of public-private partnership]. Innovatsiina ekonomika - Innovative Economy, 1-2(78), 13-24. Retrieved from http://inneco.org/index. $\mathrm{php} /$ innecoua/article/view/4/5 [in Ukrainian].

28. Report of the World Commission on Environment and Development: Our Common Future. (n.d.). sustainabledevelopment.un.org. Retrieved from https://sustainabledevelopment.un.org/content/documents / 5987our-common-future.pdf [in English].

29. Jomo K. S., Chowdhury A., Sharma K., Platz D. (2016). Public-Private Partnerships and the 2030 Agenda for Sustainable Development: Fit for purpose? DESA Working Paper № $\quad 148 \mathrm{ST} / \mathrm{ESA} / 2016 / \mathrm{DWP} / 148$. wror.un.org. Retrieved from https:// www.un.org/esa/desa/papers/2016/ wp148_2016.pdf [in English].

30. Green Paper on public-private partnerships and Community law on public contracts and concessions (presented by the Commission). (2004). op.europa.eu. Retrieved from https:// op.europa.eu/en/publication-detail/-/publication/94a3f02f-ab6a47ed-b6b2-7de60830625e/languageen [in English].

31. Guidebook on Promoting Good Governance in Public-Private Partnerships. (2008). New York and Geneva: United Nations Economic Commission for Europe. Retrieved from https://www. unece.org/fileadmin/DAM/ceci/publications/ppp.pdf [in English].
32. Zakon Ukrainy "Pro derzhavno-pryvatne partnerstvo" : vid 01.07.2010, № 2404-VI [Law of Ukraine "On public-private partnership" from 01.07.2010, № 2404-VI]. zakon.rada. gov.ua. Retrieved from https://zakon.rada.gov.ua/laws/show/240417\#Text [in Ukrainian].

33. Zakon Ukrainy "Pro kontsesiiu" : vid 03.10.2019, № 155-IX [Law of Ukraine "On the concession" from 03.10.2019, № 155-IX]. zakon.rada. gov.ua. Retrieved from https://zakon. rada.gov.ua/laws/show/155-20\#Text [in Ukrainian].

34. Postanova Kabinetu Ministriv Ukrainy "Deiaki pytannia orhanizatsii zdiisnennia derzhavno-pryvatnoho partnerstva” : vid 11.04.2011 № 384 [Resolution of the Cabinet of Ministers of Ukraine "Some issues of the organization of public-private partnership" from 11.04.2011, № 384]. zakon. rada.gov.ua. Retrieved from https:// zakon.rada.gov.ua/laws/show/3842011-\%D0\%BF\#Text [in Ukrainian].

35. Postanova Kabinetu Ministriv Ukrainy "Pro zatverdzhennia Metodyky vyiavlennia ryzykiv zdiisnennia derzhavno-pryvatnoho partnerstva, yikh otsinky ta vyznachennia formy upravlinnia nymy" : vid 16.02.2011, № 232 [Resolution of the Cabinet of Ministers of Ukraine "On Approval of the Methodology for Identifying the Risks of Public-Private Partnerships, Their Assessment and Determining the Form of Their Management" from 16.02.2011 № 232]. zakon.rada. gov.ua. Retrieved from https://zakon. rada.gov.ua/laws/show/232-2011$\% \mathrm{D} 0 \% \mathrm{BF}$ \# Text [in Ukrainian].

36. Nakaz Ministerstva Ekonomichnoho Rozvytku i Torhivli Ukrainy "Deiaki pytannia provedennia analizu efektyvnosti zdiisnennia derzhavnopryvatnoho partnerstva Minekonomrozvytku Ukrainy” : vid 27.02.2012, 
№ 255 [Order of Ministry of Economic Development and Trade of Ukraine "Some issues of analysis of the effectiveness of public-private partnership of the Ministry of Economic Development of Ukraine" from 27.02.2012, № 255]. zakon.rada.gov.ua. Retrieved from https://zakon.rada.gov.ua/laws/ show/z0399-12\#Text [in Ukrainian].

37. Nakaz Ministerstva Rozvytku Ekonomiky, Torhivli ta Silskoho Hospodarstva Ukrainy "Pro zatverdzhennia Poriadku podannia derzhavnymy partneramy (kontsesiiedavtsiamy) shchorichnoho zvitu pro vykonannia dohovoru, ukladenoho v ramkakh derzhavno-pryvatnoho partnerstva" : vid 26.05.2020, № 986 [Order of the Ministry of Economic Development, Trade and Agriculture of Ukraine "On approval of the Procedure for submission by state partners (concessionaires) of the annual report on implementation of the agreement concluded within the framework of public-private partnership" from 26.05.2020, № 986]. zakon. rada.gov.ua. Retrieved from https:// zakon.rada.gov.ua/laws/show/z062820\#Text [in Ukrainian].

38. Postanova Kabinetu Ministriv Ukrainy "Pro zatverdzhennia Poriad- ku zaminy pryvatnoho partnera (kontsesionera) za dohovorom, ukladenym v ramkakh derzhavno-pryvatnoho partnerstva (kontsesiinym dohovorom)" : vid 01.07.2020, № 541 [Resolution of the Cabinet of Ministers of Ukraine "On approval of the Procedure for replacement of a private partner (concessionaire) under an agreement concluded within the framework of a public-private partnership (concession agreement)" from 01.07.2020, № 541]. zakon.rada.gov.ua. Retrieved from https://zakon.rada.gov.ua/laws/ show/541-2020-\%D0\%BF\#Text [in Ukrainian].

39. Postanova Kabinetu Ministriv Ukrainy "Pro zatverdzhennia Poriadku povernennia kontsesiiedavtsiu obiekta kontsesii pislia prypynennia dii kontsesiinoho dohovoru" : vid 22.07.2020, № 621 [Resolution of the Cabinet of Ministers of Ukraine "On approval of the Procedure for returning the concession object to the concessionaire after the termination of the concession agreement” from 22.07.2020, № 621]. zakon.rada.gov.ua. Retrieved from https://zakon.rada.gov.ua/laws/ show/621-2020-\%D0\%BF\#Text [in Ukrainian]. 